\title{
Výskyty hydrotermálnej Sb-Au mineralizácie na lokalitách Lomnistá, Husárka a Suchá dolina pri Jasení (Nízke Tatry)
}

\author{
Occurrences of hydrothermal Sb-Au mineralization at Lomnistá, Husárka and Suchá \\ dolina near Jasenie (Nízke Tatry Mts.)
}

\author{
Štefan Čík ${ }^{1)}$, Martin Chovan ${ }^{1)}$ a Juraj Majzlan ${ }^{2 * *}$ \\ 1)Katedra mineralógie a petrológie Prírodovedeckej fakulty Univerzity Komenského Bratislava, Ilkovičova 6, \\ 84215 Bratislava, Slovensko \\ 2)Institut für Geowissenschaften, Friedrich-Schiller-Universität Jena, Burgweg 11, 07749 Jena, Německo; \\ *e-mail: Juraj.Majzlan@uni-jena.de
}

Čí Š, Chovan M, MaJzLAN J (2020) Výskyty hydrotermálnej Sb-Au mineralizácie na lokalitách Lomnistá, Husárka a Suchá dolina pri Jasení (Nízke Tatry). Bull Mineral Petrolog 28(1): 210-218 ISSN 2570-7337

\begin{abstract}
Ore mineralization in small Sb-Au occurrences Lomnistá, Husárka and Suchá dolina (Nízke Tatry Mts., Western Carpathians) was investigated by reflected-light microscopy, electron microprobe, fluid inclusion measurements, identification of host rock alteration and secondary minerals. Hydrothermal Sb-Au mineralization was formed during the arsenopyrite-pyrite-gold and stibnite-Pb-Sb-sulfosalts stages. The first stage of mineralization consists of arsenopyrite, pyrite, and quartz, but gold, typical for this stage in the Nízke Tatry Mts., is missing. Stibnite and zinkenite are dominant in the following stage in Lomnistá and Husárka. Berthierite and jamesonite are frequent in Suchá dolina. Other ore minerals identified here are sphalerite, chalcostibite, chalcopyrite, cinnabar, tetrahedrite-(Hg) at Lomnistá and Husárka and pyrrhotite, chalcostibite, tetrahedrite-(Fe), chalcopyrite, antimony, and gold in Suchá dolina. Identified secondary minerals are valentinite and stibiconite. Stibnite, gold, and other ore minerals were found in heavy-mineral fractions from alluvial sediments, pointing to short transport from the primary sources. Two quartz samples, thought to be related to stibnite or berthierite, contained two-phase fluid inclusions with salinity of $10-20 \mathrm{wt} \% \mathrm{NaCl}$ eq. The total homogenization temperatures are $230-330{ }^{\circ} \mathrm{C}$ in Lomnistá and $200-260{ }^{\circ} \mathrm{C}$ in Suchá dolina.
\end{abstract}

Key words: Sb-Au mineralization, Lomnistá, Husárka, Suchá dolina, Nízke Tatry Mts.

Obdrženo 20. 4. 2020; prijato 5. 6. 2020

\section{Úvod}

Tatrické kryštalinikum Ďumbierskych Nízkych Tatier je známe svojimi výskytmi rôznych typov hydrotermálnych rudných mineralizácií. Chovan et al. (1996; 1998) a Majzlan et al. (2020) rozčlenili rudné mineralizácie podla ich minerálneho a chemického obsahu. $Z$ historického a ekonomického hl'adiska boli najvýznamnejšie mineralizácie zlatá s arzenopyritom a pyritom (napr. ložiská Magurka, Dve Vody) a antimonitová (napr. ložiská Dúbrava, Lom, Medzibrod). Žily so sideritom, kremeňom a Cu sulfidmi sa koncentrujú najmä na východnom okraji Ďumbierskych Nízkych Tatier, napríklad v oblasti Vyšnej Boce (Ozdín a Chovan 1999). Napriek intenzívnemu mineralogickému, geochemickému a metalogenetickému výskumu rudných lokalít v tejto oblasti za posledné desat'ročia zostáva ešte stále niekol'ko výskytov, ktoré neboli spracované modernými metódami.

Niekol'ko takýchto výskytov sa nachádza na južných svahoch pohoria, severne od obce Jasenie (obr. 1). Z hl'adiska ložiskovo-geologického patrí chotár obce Jasenie k jedným z najpestrejších rudných rajónov v Nízkych Tatrách (Slavkay 1971; Koděra et al. 1986). Okrem výskytov, ktoré sú predmetom tejto práce, je vel'mi dobre známe polymetalické ložisko Jasenie - Soviansko (Pouba, Vejnar
1955; Luptáková, Pršek 2004; Luptáková 2007), scheelitová mineralizácia v oblasti Jasenie - Kyslá, skúmaná ako potenciálne ložisko volfrámu (Beňka, Suchý 1983) alebo drobné sideritovo-sulfidické žily (Hak 1966).

$\checkmark$ tomto príspevku sú zhrnuté výsledky mineralogického štúdia hydrotermálnych minerálov Sb mineralizácie na lokalitách Lomnistá, Husárka a Suchá dolina. Údaje o primárnych a sekundárnych rudných a nerudných mineráloch sú doplnené výsledkami šlichovej prospekcie, štúdiom okoložilných alterácií a fluidných inklúzií.

\section{Geologicko-ložisková charakteristika}

Skúmané lokality sa nachádzajú $v$ Ďumbierskych Nízkych Tatrách (obr. 1), tvorených varískym tatrickým kryštalinikom, jeho autochtónnym mladopaleozoicko-mezozoickým obalom a alochtónnymi mezozoickými sekvenciami. Granitoidy sú významne zastúpené v kryštaliniku, a to predovšetkým $v$ jeho severnej časti a sú rozdelené do dvoch genetických typov. Prvú skupinu predstavujú peraluminózne granitoidy typu $\mathrm{S}$, kam patria granitoidy typu Králička a Latiborská hol'a. Druhú skupinu tvoria postorogénne granitoidy typu I, ku ktorým patria granitoidy typu Prašivá a Ďumbier (Petrík et al. 1994). Okrem granitoidov sa na stavbe kryštalinika Ďumbierskych Nízkych 
Tatier podiel'ajú aj žily pegmatitov a aplitov, tiež kremenné diority a porfýry. Z metamorfovaných hornín vyskytujúcich sa predovšetkým v južnej časti pohoria sú v prevahe biotitické a dvojsl'udné ruly, zriedkavejšie sú amfibolické ruly (Putiš et al. 1992). Obal kryštalinika pozostáva s mlado- paleozoických zlepencov a arkózových metadrob, mezozoikum je zastúpené lúžňanským súvrstvím (kremencami a drobami), tiež doskovitými a ramsauskými dolomitmi, sivými lavicovitými vápencami, kremitými vápencami a rádiolaritmi (Biely et al. 1998).

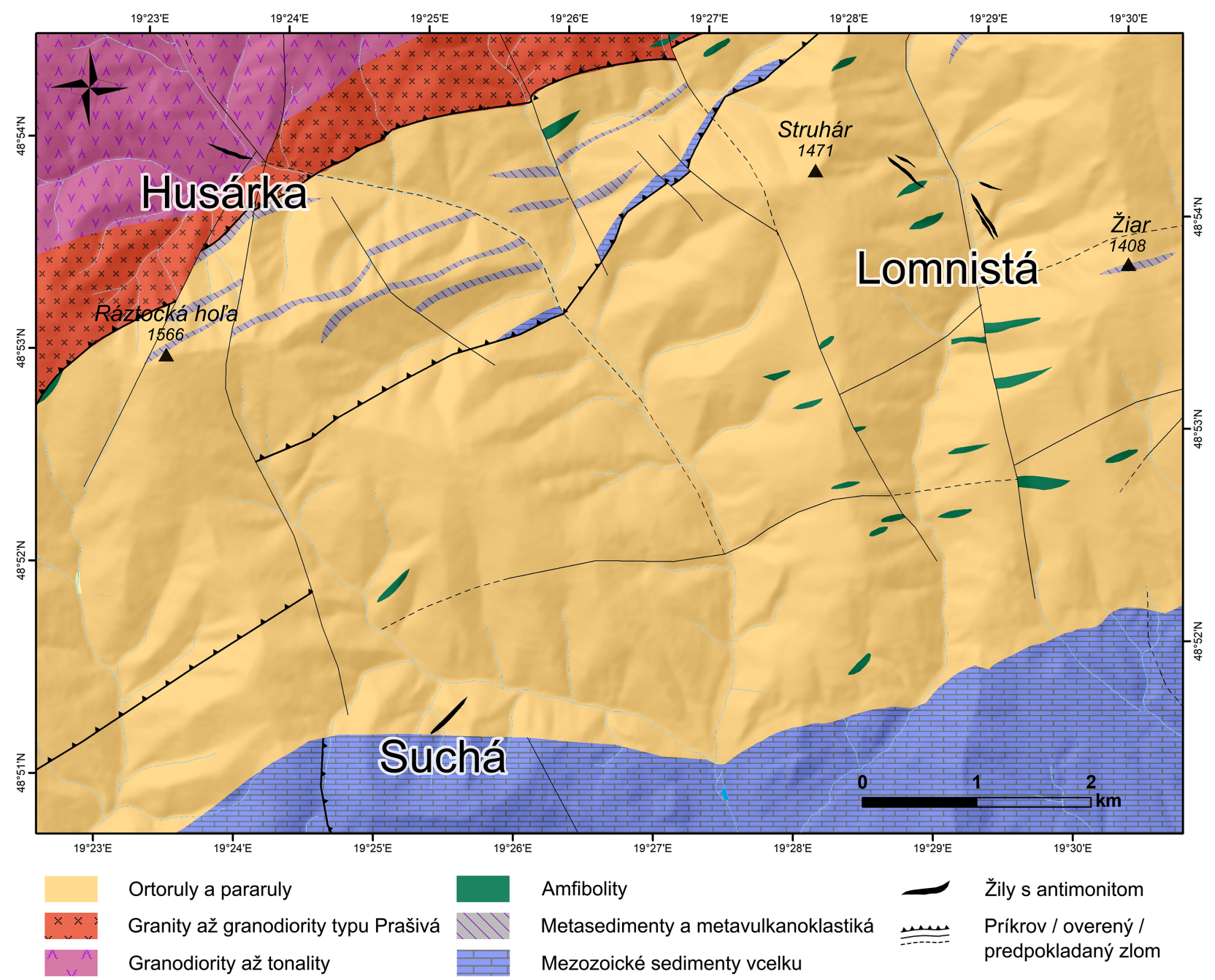

Obr. 1 Geologická mapa územia severne od Jasenia s vyznačením študovaných výskytov. Zjednodušené podla Bieleho et al. (1998), priebeh rudných žíl podla Slavkaya (1971).

Tabul'ka 1 Lokalizácia vybraných háld a prieskumných prác, z ktorých boli odoberané vzorky pre túto štúdiu. Súradnice sú udávané v severnej zemepisnej širke a východnej zemepisnej dížke.

\begin{tabular}{|c|c|c|}
\hline z. šírka & z. dížka & lokalita a poznámky \\
\hline $48^{\circ} 53^{\prime} 54^{\prime \prime}$ & $19^{\circ} 28^{\prime} 53^{\prime \prime}$ & Lomnistá, Dolná Anton štôlňa, asi 20 m od ústia \\
\hline $48^{\circ} 53^{\prime} 53^{\prime \prime}$ & $19^{\circ} 28^{\prime} 58^{\prime \prime}$ & Lomnistá, Horná Anton štôlňa, asi 50 m sv. od ústia \\
\hline $48^{\circ} 53^{\prime} 53^{\prime \prime}$ & $19^{\circ} 28^{\prime} 55^{\prime \prime}$ & Lomnistá, rozvezená halda asi 25 m pod ústím Hornej Anton štôlne \\
\hline $48^{\circ} 54^{\prime} 6^{\prime \prime}$ & $19^{\circ} 28^{\prime} 25^{\prime \prime}$ & Lomnistá, halda štôlne Emília \\
\hline $48^{\circ} 54^{\prime} 9^{\prime \prime}$ & $19^{\circ} 28^{\prime} 21^{\prime \prime}$ & Lomnistá, halda štôlne Gregor \\
\hline $48^{\circ} 54^{\prime} 9^{\prime \prime}$ & $19^{\circ} 28^{\prime} 18^{\prime \prime}$ & Lomnistá, halda štôlne Jozef \\
\hline $48^{\circ} 53^{\prime} 55^{\prime \prime}$ & $19^{\circ} 23^{\prime} 28^{\prime \prime}$ & Husárka, halda nad lesnou cestou blízko potoka Husárka \\
\hline $48^{\circ} 53^{\prime} 50^{\prime \prime}$ & $19^{\circ} 23^{\prime} 30^{\prime \prime}$ & Husárka, 30 m nad starou štôlňou a vel'kou haldou \\
\hline $48^{\circ} 51^{\prime} 31^{\prime \prime}$ & $19^{\circ} 25^{\prime} 14^{\prime \prime}$ & Suchá dolina, halda so zavalenou štôlňou \\
\hline $48^{\circ} 51^{\prime} 31^{\prime \prime}$ & $19^{\circ} 25^{\prime} 24^{\prime \prime}$ & Suchá dolina, najvyššia halda so zavalenou štôlňou \\
\hline $48^{\circ} 51^{\prime} 29^{\prime \prime}$ & $19^{\circ} 25^{\prime} 25^{\prime \prime}$ & Suchá dolina, asi 30 m nad predošlým výskytom, najväčšia halda \\
\hline $48^{\circ} 51^{\prime} 30^{\prime \prime}$ & $19^{\circ} 25^{\prime} 23^{\prime \prime}$ & Suchá dolina, halda \\
\hline $48^{\circ} 53^{\prime} 6^{\prime \prime}$ & $19^{\circ} 33^{\prime} 9^{\prime \prime}$ & Lom, najvýchodnejšia halda \\
\hline $48^{\circ} 52^{\prime} 57^{\prime \prime}$ & $19^{\circ} 33^{\prime} 17^{\prime \prime}$ & Lom, prieskumná ryha \\
\hline
\end{tabular}


Rudné telesá v Lomnistej a v Suchej doline sú podl'a Slavkaya (1971) a Michálka (1988) umiestnené v prostredí rúl a migmatitov, na Husárke však v mylonitizovanom granite typu Prašivá. Metamorfované horniny sú lokálne prenikané žilami pegmatitov a aplitov a sú zvrásnené do mikrovrás i vrás mezoskopických rozmerov (Slavkay 1971). Výsledky mineralogického výskumu na lokalitách Lomnistá a Husárka publikoval Hak (1966). Neskôr v rokoch 1970 - 1971 sa na ložisku Lomnistá vykonával základný ložiskovo-geologický prieskum a toto ložisko bolo aj krátko t’ažené. Na Husárke sa uskutočnili len prieskumné bansko-geologické práce s ciel'om overit' zásoby Sb rúd, ku t’ažbe však nikdy nedošlo (Slavkay 1971).

Údolie potoka Lomnistá rozdeluje ložisko na dve časti - na západnú a východnú (obr. 1). Celkovo sa na ložisku vyčlenilo sedem rudných štruktúr, v západnej časti sú dve z nich, východná čast' ložiska sa delí na severnú, strednú a južnú. Najvýznamnejšia a najbohatšia je stredná zóna východnej časti ložiska, ktorá sa sprístupnila pri prieskumných prácach Hornou a Dolnou Anton štôlňou. Rudné zóny majú smernú dížku 150 až 250 m, výrazne strmý sklon 70 - 90 k JZ, hrúbka žíl je od 0.1 do $1.6 \mathrm{~m}$ a híbkový dosah je do 70 m (Slavkay 1971). Na tomto ložisku je podl'a Haka (1966) žilná výplň vel'mi nepravidelná a má charakter šošoviek, niekedy s prechodom do impregnácií v okolitých horninách. Na zložení žilnej výplne sa $v$ podstatnej miere zúčastňuje kremeň $s$ antimonitom, menej jamesonit a berthierit (Hak 1966; Slavkay 1971).

Výplň rudných žil pozostáva z mliečnobieleho kremeňa, sivého Fe-bohatého dolomitu, zriedkavo je prítomný tiež siderit, albit a ankerit. $Z$ rudných minerálov je najhojnejší antimonit, menej hojný je berthierit, pyrit, ja- mesonit, vzácne arzenopyrit, chalkopyrit, hematit, pyrotit, sfalerit a zlato, sekundárny je kermezit a valentinit (Slavkay 1971; Michálek 1988).

Ložisko Husárka je situované v oblasti sútoku Bieleho potoka a Husárky, približne $7 \mathrm{~km} \mathrm{SSZ} \mathrm{od} \mathrm{Jasenia.}$ Rudné žilky sú niekol'ko $\mathrm{cm}$ až dm hrubé, prípadne $\mathrm{Sb}$ ruda tvorí ploché, kulisovito usporiadané šošovky. Smerná dížka rudnej zóny je do $250 \mathrm{~m}$, pričom jednotlivé časti majú rozsah do $30 \mathrm{~m}$. Smer rudných žíl je SV - JZ, ich sklon je $30^{\circ} \mathrm{k}$ JV (Slavkay 1971).

Jemne kryštalický až liaty antimonit je najbežnejší rudný minerál, menej hojný je drobnozrnný idiomorfný pyrit, vzácne arzenopyrit, galenit, sfalerit, chalkopyrit, rutil, zinkenit a zlato (Hak 1966; Slavkay 1971; Michálek 1988). Z nerudných minerálov na žilách prevláda modrastosivý kremeň, menej rozšírený je sivý Fe-bohatý dolomit.

Výskyty Sb rúd v Suchej doline sú situované na severovýchodné úbočia Čierneho dielu, západne od obce Jasenie. Samotná mineralizácia je situovaná do mylonitizovaných zón migmatitov, ktoré prebiehajú $v$ smere 45 - $50^{\circ} \mathrm{s}$ úklonom $20-30^{\circ} \mathrm{k} \mathrm{JV}$. Žilné pásmo má smernú dížku od 250 do $300 \mathrm{~m}$, antimonitové žilky so zlatom v nej vyvinuté majú $s$ ňou zhodný smerný i híbkový priebeh. Híbkový dosah zrudnenia nebol preskúmaný, vývoj kremenno-antimonitových žiliek $v$ rudnej zóne je kolísavý, ich priemerná mocnost' sa pohybuje v rozpätí $0.2-2 \mathrm{~cm}$, len výnimočne až do $8 \mathrm{~cm}$ (Michálek 1988).

Žilky rudnej mineralizácie sú tvorené mliečnobielym kremeňom a drobnozrnným antimonitom $\mathrm{v}$ mylonitizovanej hornine. Zriedkavejšie minerály sú sfalerit, galenit, jamesonit, siderit, tetraedrit a zlato (Hak 1966; Slavkay 1971; Michálek 1988).
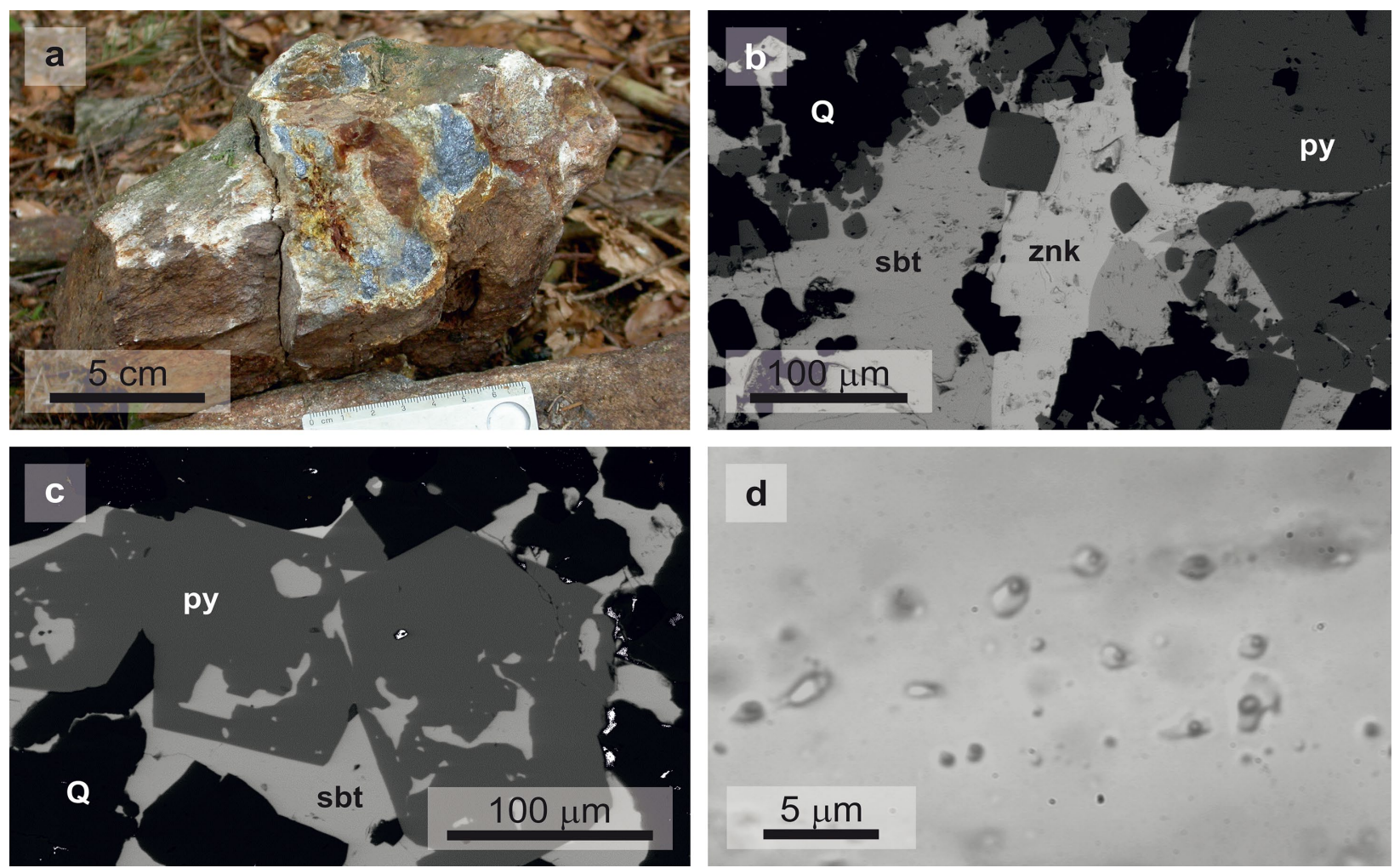

Obr. 2 Makrofotografia rudnej žiloviny (a) a mikrofotografie v spätne rozptýlených elektrónoch (b,c) a prechádzajúcom polarizovanom svetle (d) z lokalít Lomnistá a Husárka. a) Antimonitová žila, lemovaná z oboch strán hydrotermálne alterovanou metamorfovanou horninou. Na vzorke sú viditel'né aj biele, žlté a hnedé sekundárne minerály. Lokalita Lomnistá. b) Prerastanie antimonitu (sbt), zinkenitu (znk) a pyritu (py) v kremeni (Q). Lokalita Husárka. c) Antimonit (sbt) zatláčaný kryštálmi pyritu (py). Lokalita Lomnistá. d) Dvojfázové fluidné inklúzie v kremeni. Lokalita Lomnistá. 


\section{Metodika}

Vzorky na štúdium hydrotermálnych mineralizácií sa odoberali zo starých háld, prieskumných rýh a šachtíc. Presnú lokalizáciu niektorých háld (GPS súradnice) uvádzame v tabul'ke 1.

Koncentráty t’ažkých minerálov, získané šlichovou prospekciou $v$ teréne, sa d’alej spracovávali v laboratóriu. Išlo o separáciu minerálov v bromoforme a magnetickou separáciou na magnetickom separátore. Koncentráty získané v teréne sa tak rozdelili na l'ahkú, magnetickú a t’ažkú frakciu. Minerály $v$ týchto frakciách boli identifikované pri pozorovaní v binokulárnej lupe. Pozornost' sa zameriavala najmä na minerály, ktoré môžu indikovat' blízkost' rudných žíl.

Minerály a minerálne asociácie sa študovali v prechádzajúcom aj odrazenom svetle na mikroskopoch Leica a Jenapol na Katedre mineralógie a petrológie na Prírodovedeckej fakulte UK (PriF UK) v Bratislave. RTG difrakčná prášková analýza sa vykonala vo VVCE SOLIPHA (PriF UK v Bratislave) na prístroji BRUKER D8 Advance v geometrii $\theta-2 \theta$ s Cu antikatódou $\left(\lambda \alpha_{1}=1.54060 \AA\right)$, Ni Kß filtrami a detektorom LynxEye, pri napätí $40 \mathrm{kV}$ a prúde $40 \mathrm{~mA}$. Krok zaznamenávania intenzít bol $0.01^{\circ} 2 \Theta$ pri čase $1 \mathrm{~s}$, meraný rozsah záznamov $4-65^{\circ} 2 \theta$. Difrakčné záznamy boli spracované pomocou programu Diffrac ${ }^{\text {plus }}$ EVA a Rietveldovou metódou v programe GSAS.

Chemické zloženie minerálov sa stanovovalo energiodisperznou (EDS) aj vinovo-disperznou (WDS) analýzou. Metódou EDS sa skúmali minerály na prístroji Jeol JXA 840 A v laboratóriu elektrónovo-optických metód na PriF UK. WDS analýzy sa vykonali na prístroji elektrónová mikrosonda CAMECA SX 100 na Štátnom geologickom ústave Dionýza Štúra (Bratislava) za nasledovných pod- mienok: urýchl'ovacie napätie 15-20 kV a priemer elektrónového lúča $1-10 \mu \mathrm{m}$. Použité štandardy a emisné línie: $\mathrm{CuFeS}_{2}(\mathrm{Cu} \mathrm{K \alpha}), \mathrm{Sb}(\mathrm{Sb} \mathrm{L} \beta), \mathrm{Ag}(\mathrm{Ag} \mathrm{La}), \mathrm{PbS}(\mathrm{Pb}$ $\mathrm{Ma}), \mathrm{HgS}(\mathrm{Hg} \mathrm{L \alpha}), \mathrm{CuFeS}_{2}(\mathrm{Fe} \mathrm{K \alpha}), \mathrm{ZnS}(\mathrm{Zn} \mathrm{K \alpha}), \mathrm{Bi}_{2} \mathrm{Se}_{3}$ (Bi La), $\mathrm{NaCl}(\mathrm{Cl} \mathrm{K \alpha})$, FeAsS (As K $\beta$ a Ka), Cd (Cd La), Co (Co Ka), Ni (Ni Ka), CuFeS 2 (S Ka). Kryštalochemické vzorce niektorých sulfidov a sulfosolí sa prepočitali na sumu katiónov zodpovedajúcich teoretickému zloženiu (Moëlo et al. 2008).

Fluidné inklúzie sa skúmali v obojstranne leštených preparátoch vyhotovených z kremeňa. Vybrané fázové prechody sa merali na mikrotermometrickom stolčeku napojenom na zariadenie LINKAM THMSG-600. Zariadenie sa kalibrovalo na známych fázových prechodoch (tavenie $\mathrm{CO}_{2}, \mathrm{H}_{2} \mathrm{O}$ a $\mathrm{K}_{2} \mathrm{Cr}_{2} \mathrm{O}_{7}$ ). V blízkosti fázových prechodov sa rýchlost' zahrievania znížila na minimum. Odhadnuté chyby merania sú $\pm 0.1^{\circ} \mathrm{C}$ pre prechody pri nízkych teplotách $\left(<0{ }^{\circ} \mathrm{C}\right) \mathrm{a} \pm 1^{\circ} \mathrm{C}$ pre vyššie teploty (celková homogenizácia, $\left.>100^{\circ} \mathrm{C}\right)$.

\section{Výsledky}

\section{Šlichová prospekcia}

V aluviálnych sedimentoch potoka Lomnistá a v Suchej doline boli skúmané obsahy t’ažkých minerálov, $\mathrm{s}$ dôrazom na indikátory zrudnenia (antimonit, zlato).

$\checkmark$ potoku Lomnistá sa v šlichoch zistil hojne antimonit, miestami pokrytý žlto-oranžovými povlakmi sekundárnych minerálov, zriedkavo sfalerit, pyrit, magnetit, hematit a zlato. Zlato sa tu nachádza v podobe zrniek vel'kosti do $1 \mathrm{~mm} \mathrm{~s}$ hákovitým povrchom, len s minimálnymi stopami ovál'ania. Preto sa predpokladá primárny pôvod a blízkost' primárneho zdroja. Z d’alších t’ažkých minerálov boli prítomné bežné granáty a zriedkavý apatit, rutil a monazit.
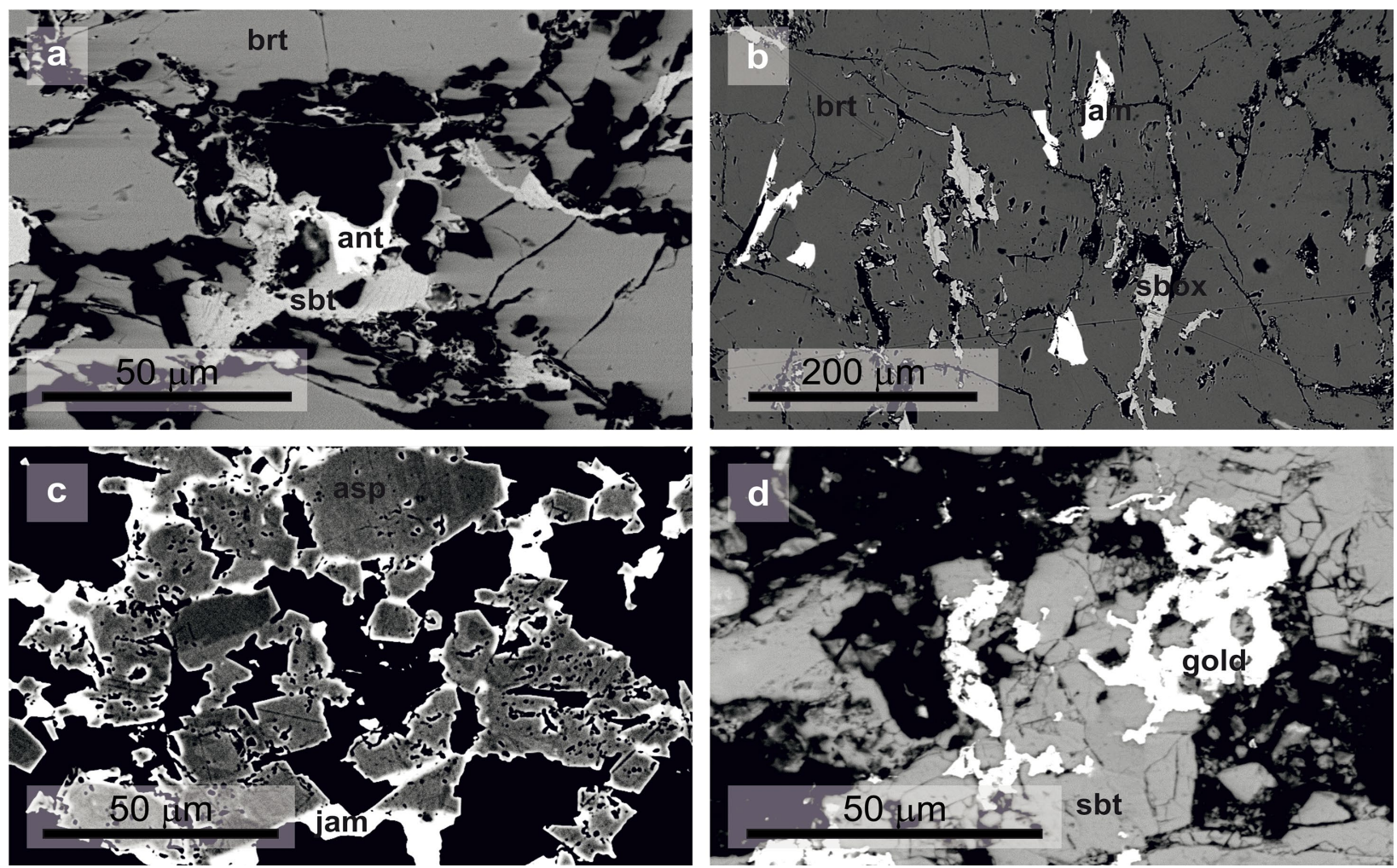

Obr. 3 Obrázky paragenéz rudných minerálov zo Suchej doliny, nasnímané pomocou spätne roztpýlených elektrónov. a) Prerastanie berthieritu (brt) a antimonitu (sbt) s drobnou inklúziou antimónu (ant). b) Inklúzie jamesonitu (jam) a bližšie neidentifikovaného primárneho Sb oxidu (Sb ox) v berthierite (brt). c) Kryštály arzenopyritu (asp) sú obrastené jamesonitom (jam). d) Agregát zlata (gold) vrastený v antimonite (sbt). 
Tabul'ka 2 Bodové chemické analýzy arzenopyritu zo Suchej doliny (vzorka Su-4-2-2).

\begin{tabular}{lrrrrrrrrrr}
\hline & 1 & 2 & 3 & 4 & 5 & 6 & 7 & 8 & 9 & 10 \\
\hline $\mathrm{S}$ & 20.44 & 20.38 & 19.96 & 20.51 & 19.35 & 19.88 & 19.62 & 19.73 & 19.77 & 19.75 \\
$\mathrm{As}$ & 44.04 & 43.52 & 44.96 & 43.68 & 45.95 & 44.96 & 45.72 & 45.41 & 45.62 & 45.28 \\
$\mathrm{Fe}$ & 35.40 & 35.70 & 35.52 & 36.16 & 34.99 & 35.79 & 35.54 & 36.76 & 35.58 & 35.42 \\
$\mathrm{Co}$ & 0.06 & 0.06 & 0.05 & 0.08 & 0.07 & 0.06 & 0.07 & 0.06 & 0.08 & 0.07 \\
$\mathrm{Sb}$ & 0.49 & 0.46 & 0.24 & 0.55 & 0.31 & 0.26 & 0.04 & 0.23 & 0.22 & 0.32 \\
\hline suma & 100.43 & 100.12 & 100.73 & 100.98 & 100.67 & 100.95 & 100.99 & 102.19 & 101.27 & 100.84 \\
\hline \multicolumn{7}{l}{ kryštalochemické koeficienty (prepočet na bázu As+S $=2$ ) } & & & & \\
\hline $\mathrm{S}$ & 1.041 & 1.045 & 1.018 & 1.046 & 0.992 & 1.016 & 1.001 & 1.008 & 1.006 & 1.009 \\
$\mathrm{As}$ & 0.959 & 0.955 & 0.982 & 0.954 & 1.008 & 0.984 & 0.999 & 0.992 & 0.994 & 0.991 \\
$\mathrm{Fe}$ & 1.035 & 1.051 & 1.040 & 1.059 & 1.030 & 1.050 & 1.041 & 1.078 & 1.040 & 1.039 \\
$\mathrm{Co}$ & 0.002 & 0.002 & 0.001 & 0.002 & 0.002 & 0.002 & 0.002 & 0.002 & 0.002 & 0.002 \\
$\mathrm{Sb}$ & 0.007 & 0.006 & 0.003 & 0.007 & 0.004 & 0.004 & 0.001 & 0.003 & 0.003 & 0.004 \\
\hline
\end{tabular}

Tabul'ka 3 Bodové chemické analýzy berthieritu zo Suchej doliny (vzorka Su-3-1-1).

\begin{tabular}{lrrrrr}
\hline & 1 & 2 & 3 & 4 & 5 \\
\hline $\mathrm{S}$ & 29.83 & 29.79 & 29.74 & 29.70 & 29.65 \\
$\mathrm{As}$ & 0.38 & 0.38 & 0.48 & 0.11 & 0.31 \\
$\mathrm{Fe}$ & 13.02 & 13.10 & 12.99 & 13.07 & 12.91 \\
$\mathrm{Sb}$ & 56.68 & 56.96 & 57.29 & 57.11 & 56.69 \\
$\mathrm{Bi}$ & 0 & 0 & 0.01 & 0.01 & 0.02 \\
$\mathrm{~Pb}$ & 0.58 & 0.46 & 0.48 & 0.45 & 0.48 \\
$\mathrm{Cu}$ & 0.02 & 0 & 0.01 & 0.01 & 0.01 \\
$\mathrm{Zn}$ & 0.02 & 0.01 & 0 & 0 & 0.02 \\
\hline suma & 100.56 & 100.74 & 101.00 & 100.57 & 100.10
\end{tabular}

kryštalochemické koeficienty (prepočet na bázu 3 katiónov)

\begin{tabular}{lrrrrr}
\hline $\mathrm{S}$ & 3.95 & 3.93 & 3.91 & 3.93 & 3.94 \\
$\mathrm{As}$ & 0.02 & 0.02 & 0.03 & 0.01 & 0.02 \\
$\mathrm{Fe}$ & 0.99 & 0.99 & 0.98 & 0.99 & 0.99 \\
$\mathrm{Sb}$ & 1.97 & 1.98 & 1.98 & 1.99 & 1.98 \\
$\mathrm{Bi}$ & 0 & 0 & 0 & 0 & 0 \\
$\mathrm{~Pb}$ & 0.01 & 0.01 & 0.01 & 0.01 & 0.01 \\
$\mathrm{Cu}$ & 0 & 0 & 0 & 0 & 0 \\
$\mathrm{Zn}$ & 0 & 0 & 0 & 0 & 0 \\
\hline
\end{tabular}

Tabul'ka 4 Bodové chemické analýzy cinabaritu z Husárky (vzorka Hus-2-A).

\begin{tabular}{lrrrrr}
\hline & 1 & 2 & 3 & 4 & 5 \\
\hline $\mathrm{S}$ & 14.20 & 14.50 & 14.26 & 13.70 & 14.85 \\
$\mathrm{Sb}$ & 0.17 & 0.66 & 0.07 & 0.11 & 0.04 \\
$\mathrm{Ag}$ & 0.04 & 0.05 & 0.13 & 0.06 & 0.07 \\
$\mathrm{Hg}$ & 84.76 & 83.53 & 84.88 & 84.89 & 83.66 \\
$\mathrm{Fe}$ & 0.01 & 0.15 & 0.02 & 0.07 & 0.65 \\
$\mathrm{Cd}$ & 0.01 & 0.01 & 0.02 & 0.01 & 0.02 \\
\hline suma & 99.19 & 98.90 & 99.38 & 98.84 & 99.29
\end{tabular}

kryštalochemické koeficienty (prepočet na bázu 1 katiónu)

\begin{tabular}{lrrrrr}
\hline $\mathrm{S}$ & 1.044 & 1.064 & 1.046 & 1.004 & 1.078 \\
$\mathrm{Sb}$ & 0.003 & 0.013 & 0.001 & 0.002 & 0.001 \\
$\mathrm{Ag}$ & 0.001 & 0.001 & 0.003 & 0.001 & 0.002 \\
$\mathrm{Hg}$ & 0.995 & 0.980 & 0.995 & 0.993 & 0.970 \\
$\mathrm{Fe}$ & 0 & 0.006 & 0.001 & 0.003 & 0.027 \\
$\mathrm{Cd}$ & 0 & 0 & 0 & 0 & 0 \\
\hline
\end{tabular}

Tabul'ka 5 Bodové chemické analýzy chalkostibitu z Husárky (vzorka Hus-2-A).

\begin{tabular}{lrrr}
\hline & 1 & 2 & 3 \\
\hline $\mathrm{S}$ & 26.02 & 25.87 & 25.76 \\
$\mathrm{Sb}$ & 48.68 & 48.15 & 47.97 \\
$\mathrm{Cu}$ & 26.05 & 26.27 & 25.68 \\
$\mathrm{~Pb}$ & 0.07 & 0.08 & 0.66 \\
$\mathrm{Hg}$ & 0.10 & 0.27 & 0.16 \\
$\mathrm{Zn}$ & 0.07 & 0.08 & 0.20 \\
\hline suma & 101.37 & 101.12 & 100.56 \\
\hline
\end{tabular}

kryštalochemické koeficienty (prepočet na bázu 2 katiónov)

\begin{tabular}{llll}
\hline $\mathrm{S}$ & 2.001 & 1.989 & 1.997 \\
$\mathrm{Sb}$ & 0.985 & 0.974 & 0.979 \\
$\mathrm{Cu}$ & 1.010 & 1.018 & 1.004 \\
$\mathrm{~Pb}$ & 0.001 & 0.001 & 0.008 \\
$\mathrm{Hg}$ & 0.001 & 0.003 & 0.002 \\
$\mathrm{Zn}$ & 0.003 & 0.003 & 0.008 \\
\hline
\end{tabular}

Vel'mi podobné mineralogické zloženie sa zistilo aj v suchých šlichoch $z$ háld a prieskumných prác $v$ Suchej doline. Zlato sa zistilo zriedkavo, v jednom prípade ( $\mathrm{z}$ troch zistených zlatiniek) malo zrnko zlata vel'kost' až $1.5 \mathrm{~mm}$.

\section{Primárne rudné minerály}

Antimonit je na lokalitách Lomnistá a Husárka hlavným rudným minerálom (obr. 2a-c), v Suchej doline je hojný, avšak v prevahe je berthierit (obr. 3a,d). Najčastejší je jemnozrnný až liaty a lištovitý antimonit, agregáty drobných ihličkovitých kryštálov sú zriedkavé. Antimonit sa väčšinou nachádza spolu s pyritom, berthieritom alebo $\mathrm{Pb}-\mathrm{Sb}$ sulfosol'ami. Miestami sa mikroskopicky pozorovalo prerastanie $s$ inými minerálmi, napríklad $s$ tetraedritom- $(\mathrm{Hg})$ a chalkostibitom (Husárka), so zlatom, sfaleritom a galenitom (Suchá dolina). Identifikovaný bol opticky a pomocou WDS analýz. Chemicky zodpovedá teoretickému zloženiu $\mathrm{Sb}_{2} \mathrm{~S}_{3}$.

Antimón sa našiel len v jednej vzorke zo Suchej doliny (obr. 3a), a to spolu $s$ antimonitom a berthieritom. Identifikovaný bol len pomocou EDS, pričom sa nezistila prítomnost' žiadnych iných prvkov.

Arzenopyrit je na všetkých troch lokalitách pomerne vzácny, vo forme hypidiomorfných a idiomorfných kryštálov, ktoré sú súčastou agregátov s pyritom. Do týchto 
agregátov preniká antimonit, a preto sa zdá, že arzenopyrit patrí k jedným z najstarších minerálov. Tiež vystupuje spolu alebo je zatláčaný jamesonitom (obr. 3c), berthieritom, tetraedritom-(Fe), rutilom, baritom, karbonátom a chalkopyritom. Pomocou WDS bol analyzovaný len arzenopyrit zo Suchej doliny (tab. 2). V jeho vzorci mierne prevláda $S$ nad As.

Berthierit je hlavný rudný minerál $v$ Suchej doline, inak je pomerne vzácny. Väčšinou ho sprevádza antimonit a pyrit, $v$ Suchej doline aj antimón, jamesonit, chalkostibit a sfalerit. V Lomnistej sa nachádza len $s$ antimonitom. Analyzoval sa len berthierit zo Suchej doliny, ktorý obsahuje mierne zvýšené koncentrácie As a $\mathrm{Pb}$ (tab. 3).

Cinabarit je vzácny, identifikoval sa pomocou elektrónovej mikroanalýzy len $v$ jednej vzorke z Husárky. Tvorí drobné alotriomorfné zrnká $(<20 \mu \mathrm{m})$ v dolomite $v$ asociácii s drobnými zrnkami Pb-Sb sulfosolí (bližšie neidentifikované), dolomitom a kremeňom. Chemicky zodpovedá teoretickému zloženiu HgS (tab. 4).

Chalkostibit je vzácny, identifikovaný mikroskopicky len na Husárke a v Suchej doline. Nachádza sa spolu $s$ berthieritom, jamesonitom, galenitom, tetraedritom-(Fe), alebo so zlatom a antimonitom. V Suchej doline je v podobe hrubotabul'kovitých lištovitých zŕn miestami obrastaný jamesonitom. Identifikovaný bol opticky aj WDS analýza- mi (tab. 5). Chemicky zodpovedá teoretickému zloženiu CuSbS.

Chalkopyrit je vzácny, ako mikroskopické zrnká s tetraedritom-(Fe) alebo tetraedritom- $(\mathrm{Hg})$ a chalkostibitom, prípadne d’alšími minerálmi, na všetkých troch lokalitách. Identifikovaný bol v odrazenom svetle.

Jamesonit je bežnejší len v Suchej doline, na Lomnistej vzácny, v podobe ihličiek a hrubotabul'kovitých agregátov. Zatláča a obal'uje arzenopyrit (obr. 3c), obrastá chalkostibit alebo tvorí inklúzie spolu s primárnym Sb oxidom $v$ berthierite. Elektrónové mikroanalýzy jamesonitu sú v tabul'ke 6.

Pyrit je spolu s antimonitom najbežnejší rudný minerál na lokalitách Lomnistá a Husárka (obr. 2b,c), v Suchej doline je zriedkavejší. Nachádza sa v 2 generáciách. Pyrit I je idiomorfný, ide väčšinou o zhluky a pyrit II je hypidiomorfný, ten vystupuje zväčša samostatne.

Pyrotit sa našiel len vzácne v Suchej doline a bol identifikovaný $v$ odrazenom svetle. Vystupuje samostatne $\checkmark$ kremeni alebo $v$ asociácii $s$ berthieritom a pyritom.

Sb oxid sa zistil len v jednej vzorke zo Suchej doliny, kde tvorí inklúzie a žilky v berthierite (obr. 3b). Podla mikrotextúr a pozície $v$ agregátoch sulfidov ho považujeme za primárny. Mikrotextúry Sb oxidu a jamesonitu, ktoré sa prerastajú s berthieritom, sú vel'mi podobné a podstatne sa líšia od textúr sekundárneho zatláčania. WDS analýzy

Tabul'ka 6 Bodové chemické analýzy jamesonitu z Lomnistej (vzorka LT-1-C) a zo Suchej doliny (vzorka Su-3-1-1).

Vzhladom na to, že boli prítomné len hlavné prvky a obsah Cu je len stopový, kryštalochemické vzorce neuvádzame.

\begin{tabular}{lrrrrrrrrr}
\hline & \multicolumn{1}{c}{ Lomnistá } & \multicolumn{6}{c}{ Suchá dolina } \\
\hline & 1 & 2 & 3 & 4 & 5 & 6 & 7 & 8 & 9 \\
\hline $\mathrm{S}$ & 22.05 & 21.98 & 22.05 & 22.02 & 21.49 & 21.60 & 22.10 & 22.03 & 22.13 \\
$\mathrm{Sb}$ & 35.53 & 35.63 & 35.60 & 36.01 & 35.88 & 35.56 & 35.96 & 35.87 & 36.03 \\
$\mathrm{Cu}$ & 0.09 & 0.05 & 0.05 & 0.07 & 0.04 & 0.06 & 0.06 & 0.11 & 0.08 \\
$\mathrm{~Pb}$ & 39.41 & 39.00 & 39.37 & 39.17 & 38.61 & 38.63 & 39.4 & 39.47 & 39.53 \\
$\mathrm{Fe}$ & 2.73 & 2.69 & 2.66 & 2.71 & 2.74 & 2.78 & 2.70 & 2.62 & 2.69 \\
\hline Total & 99.81 & 99.35 & 99.73 & 99.98 & 98.76 & 98.63 & 100.30 & 100.17 & 100.52 \\
\hline
\end{tabular}

Tabul'ka 7 Bodové chemické analýzy tetraedritu-(Hg) z Husárky (analýzy 1-6, vzorka HUS-2A) a tetraedritu-(Fe) zo Suchej doliny (analýzy 7-9, vzorka Su-3-1-1). n.a. = neanalyzované

\begin{tabular}{lrrrrrrrrr}
\hline & 1 & 2 & 3 & 4 & 5 & 6 & 7 & 8 & 9 \\
\hline $\mathrm{Ag}$ & 4.11 & 4.26 & 3.46 & 4.24 & 4.21 & 4.9 & 4.21 & 4.45 & 4.58 \\
$\mathrm{~S}$ & 22.40 & 22.31 & 22.68 & 22.89 & 22.74 & 23.13 & 24.98 & 24.93 & 24.80 \\
$\mathrm{Cu}$ & 31.03 & 31.39 & 32.68 & 31.78 & 32.51 & 32.57 & 34.82 & 34.86 & 34.50 \\
$\mathrm{Hg}$ & 12.82 & 11.94 & 10.18 & 13.11 & 12.35 & 11.36 & n.a. & n.a. & n.a. \\
$\mathrm{Pb}$ & n.a. & n.a. & n.a. & n.a. & n.a. & n.a. & 0.06 & 0.05 & 0.07 \\
$\mathrm{Sb}$ & 25.81 & 26.04 & 25.91 & 25.29 & 25.21 & 25.57 & 28.91 & 28.98 & 28.88 \\
$\mathrm{Fe}$ & 0.10 & 0.11 & 0.09 & 0.13 & 0.11 & 0.16 & 5.24 & 5.18 & 5.30 \\
$\mathrm{Zn}$ & 3.17 & 3.17 & 3.08 & 3.21 & 3.24 & 3.21 & 1.69 & 1.79 & 1.67 \\
$\mathrm{As}$ & 0.43 & 0.48 & 0.43 & 0 & 0 & 0.04 & 0.44 & 0.3 & 0.44 \\
\hline suma & 99.99 & 99.85 & 98.71 & 100.67 & 100.56 & 101.20 & 100.47 & 100.57 & 100.49 \\
\hline $\mathrm{kryštalochemické} \mathrm{koeficienty} \mathrm{(prepočet} \mathrm{na} \mathrm{bázu}$ & 16 katiónov) & & & & & \\
\hline $\mathrm{Ag}$ & 0.71 & 0.73 & 0.59 & 0.73 & 0.72 & 0.83 & 0.66 & 0.69 & 0.72 \\
$\mathrm{~S}$ & 13.02 & 12.89 & 13.09 & 13.22 & 13.03 & 13.16 & 13.12 & 13.06 & 13.04 \\
$\mathrm{Cu}$ & 9.10 & 9.15 & 9.52 & 9.26 & 9.40 & 9.35 & 9.23 & 9.22 & 9.15 \\
$\mathrm{Hg}$ & 1.19 & 1.10 & 0.94 & 1.21 & 1.13 & 1.03 & & 0 & 0 \\
$\mathrm{~Pb}$ & & & & & & & & 0.01 \\
$\mathrm{Sb}$ & 3.95 & 3.96 & 3.94 & 3.85 & 3.80 & 3.83 & 4.00 & 4.00 & 4.00 \\
$\mathrm{Fe}$ & 0.03 & 0.04 & 0.03 & 0.04 & 0.04 & 0.05 & 1.58 & 1.56 & 1.60 \\
$\mathrm{Zn}$ & 0.90 & 0.90 & 0.87 & 0.91 & 0.91 & 0.90 & 0.44 & 0.46 & 0.43 \\
$\mathrm{As}$ & 0.11 & 0.12 & 0.11 & 0 & 0 & 0.01 & 0.10 & 0.07 & 0.10 \\
\hline
\end{tabular}


zistili len prítomnost' Sb a stôp As (do 0.37 hm.\%), vel'mi pravdepodobne ide o valentinit alebo senarmontit.

Sfalerit je vzácny, na Husárke aj v Suchej doline. Nachádza sa $v$ kremeni a $v$ antimonite. Identifikovaný bol $v$ odrazenom svetle.

Tetraedrit je zriedkavý, len mikroskopický. Na Husárke sa prerastá s antimonitom a chalkostibitom v kremenno-karbonátovej žilovine a má vysoké obsahy $\mathrm{Hg}$ (tab. 7). Podla pomeru $\mathrm{Hg} /(\mathrm{Hg}+\mathrm{Fe}+\mathrm{Zn})$, ktorý je vyšší ako 0.5, patrí k tetraedritu- $(\mathrm{Hg})$ (Biagioni et al. 2019, 2020). Zaznamenal sa aj v jednej vzorke zo Suchej doliny ako inklúzia $v$ chalkostibite. Tu prevláda jednoznačne $\mathrm{Sb}$ nad As a Fe prevláda nad Zn (tab. 7), ortut' chýba, a preto patrí k tetraedritu-(Fe) (Biagioni et al. 2020). V obidvoch prípadoch sa zaznamenal zvýšený obsah Ag.

Zinkenit je najhojnejšou sulfosol'ou v Lomnistej (obr. 2b) a tiež je hojný na Husárke. Alotriomorfné až ihličkovité agregáty vystupujú spolu $\mathrm{s}$ antimonitom, pyritom a kremeňom. Identifikovaný bol $v$ odrazenom svetle a pomocou WDS analýz (tab. 8).

Zlato je vzácne, nájdené len v jednej vzorke zo Suchej doliny (obr. 3d), aj ked' ho Slavkay (1971) opísal aj z Lomnistej a Husárky. V našej vzorke sa nachádza na antimonitovej žilke v kremeni (obr. 3d).

\section{Nerudné minerály}

Barit je vzácny a našiel sa len $v$ jednej vzorke $z$ Husárky, v nej tvorí žilku s rudnými minerálmi. Vystupuje spolu $\mathrm{s}$ antimonitom, tetraedritom- $(\mathrm{Hg})$, chalkostibitom a karbonátom v kremeni. Identifikovaný bol pomocou EDS.

Kremeň je najhojnejší minerál na lokalitách Lomnistá a Husárka, v Suchej doline je menej hojný, pravdepodobne vznikal v 2 generáciách. Kremeň I je starší, tvorí hlavne žilky a žily, často $v$ ňom pozorovat' inklúzie rudných minerálov. Kremeň II je o niečo mladší a je hrubo kryštalický, bud” "obteká“ zrná pyritu, alebo vystupuje v podobe drobných inklúzií v antimonite spolu so sfaleritom a pyritom prípadne preráža vo forme žiliek antimonit a v ňom uzavretý drobný kremeň I.

Karbonát - pomocou EDS sa identifikoval ako Fe-bohatý dolomit. Je menej hojný ako kremeň, s ktorým tvorí bud' žilky alebo je vo forme samostatných zín v kremeni. $\checkmark$ Lomnistej je Fe-bohatý dolomit v paragenéze s kremeňom, antimonitom a zinkenitom. Na Husárke sa nachádza $v$ paragenéze s cinabaritom, $\mathrm{Pb}-\mathrm{Sb}$ sulfosol'ami a kremeňom, alebo s tetraedritom- $(\mathrm{Hg})$ a baritom. V Suchej doline býva tiež hojný, makroskopicky vo forme tmavohnedých romboédrov, ktoré vystupujú $v$ asociácii spolu s kremeňom, berthieritom, jamesonitom a chalkostibitom.

Tabul'ka 8 Bodové chemické analýzy zinkenitu z Lomnistej (analýzy 1-3, vzorka LT-2-5) a Husárky (analýzy 4-9, HUS-2A).

\begin{tabular}{lrrrrrrrrr}
\hline & 1 & 2 & 3 & 4 & 5 & 6 & 7 & 8 & 9 \\
\hline $\mathrm{Ag}$ & 0.04 & 0.05 & 0.05 & 0.17 & 0.15 & 0.20 & 0.19 & 0.20 & 0.17 \\
$\mathrm{~S}$ & 22.09 & 21.85 & 22.15 & 22.72 & 22.34 & 22.52 & 22.67 & 23.02 & 22.81 \\
$\mathrm{Cu}$ & 0.32 & 0.31 & 0.31 & 0.29 & 0.29 & 0.35 & 0.29 & 0.30 & 0.31 \\
$\mathrm{Sb}$ & 43.55 & 43.65 & 44.09 & 44.88 & 44.86 & 44.72 & 44.13 & 44.88 & 43.64 \\
$\mathrm{Bi}$ & 0.17 & 0.14 & 0 & 0.02 & 0.35 & 0.08 & 0.10 & 0.09 & 0 \\
$\mathrm{~Pb}$ & 30.42 & 30.60 & 30.74 & 31.06 & 30.93 & 31.05 & 30.79 & 31.08 & 30.95 \\
$\mathrm{As}$ & 0.35 & 0.33 & 0.36 & 0.05 & 0.08 & 0.07 & 0 & 0 & 0 \\
\hline Total & 96.94 & 96.93 & 97.70 & 99.19 & 99.00 & 98.99 & 98.17 & 99.57 & 97.88 \\
\hline $\mathrm{kryštalochemické} \mathrm{koeficienty} \mathrm{(prepočet} \mathrm{na} \mathrm{bázu} 31$ katiónov) & & & & 0.17 & 0.11 & 0.10 \\
\hline $\mathrm{Ag}$ & 0.02 & 0.03 & 0.03 & 0.09 & 0.08 & 0.11 & 0.10 & 42.35 & 42.88 \\
$\mathrm{~S}$ & 41.43 & 40.88 & 41.13 & 41.80 & 41.04 & 41.40 & 42.33 & 42.35 \\
$\mathrm{Cu}$ & 0.30 & 0.29 & 0.29 & 0.27 & 0.27 & 0.33 & 0.27 & 0.28 & 0.30 \\
$\mathrm{Sb}$ & 21.51 & 21.51 & 21.56 & 21.75 & 21.70 & 21.65 & 21.70 & 21.74 & 21.60 \\
$\mathrm{Bi}$ & 0.05 & 0.04 & 0 & 0.01 & 0.10 & 0.02 & 0.03 & 0.02 & 0 \\
$\mathrm{~Pb}$ & 8.83 & 8.86 & 8.84 & 8.85 & 8.79 & 8.83 & 8.90 & 8.85 & 9.01 \\
$\mathrm{As}$ & 0.28 & 0.27 & 0.29 & 0.04 & 0.06 & 0.06 & 0 & 0 & 0 \\
\hline
\end{tabular}

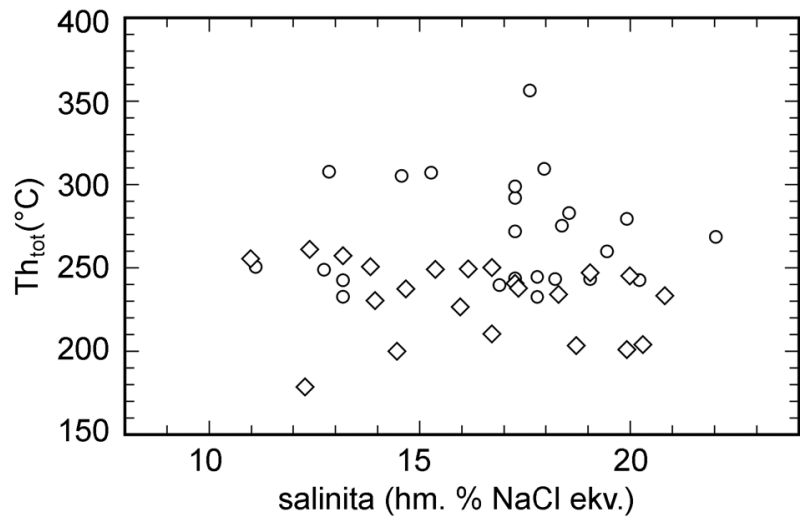

Obr. 4 Salinita a celkové homogenizačné teploty (Th $\left.{ }_{\text {tot }}\right)$ fluidných inklúzií z Lomnistej (krúžky) a Suchej doliny (otočené štvorce).

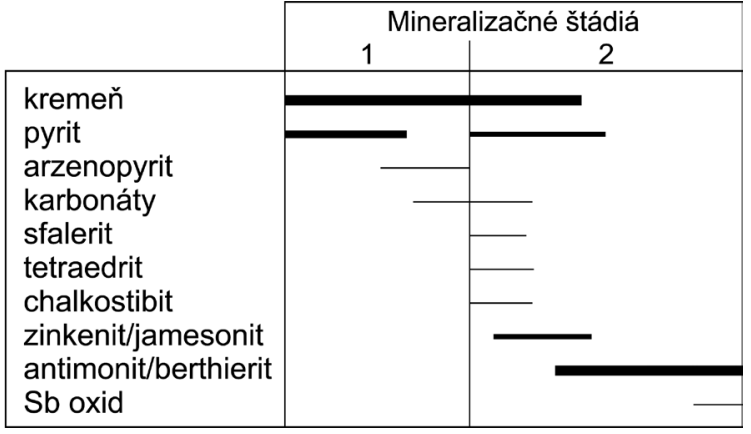

Obr. 5 Sukcesná schéma pre všetky tri skúmané lokality. Detaily sú diskutované $v$ texte. Štádium 1 zodpovedá arzenopyritovo-pyritovo-zlatému štádiu, štádium 2 zodpovedá štádiu antimonitu a Pb-Sb sulfosolí podla Majzlana et al. (2020). 


\section{Sekundárne minerály}

Stibiconit je na skúmaných lokalitách najhojnejši sekundárny minerál, makroskopicky tvorí miestami 2 - 5 $\mathrm{mm}$ hrubé, biele, žlté alebo hnedé povlaky a kôry na antimonite, tiež sýtožlté kôry a poprašky v dutinách kremeňa i okolo zŕn antimonitu. Práškové RTG difrakčné záznamy poukázali na jeho dobrú kryštalinitu. Vypočítané mriežkové parametre ( $a=10.25,10.27 \AA$, Lomnistá; $a=10.46$ Husárka; $a=9.39 \AA$, Suchá dolina) sú v dobrej zhode $\mathrm{s}$ inými publikovanými údajmi pre tento minerál (napr. Handbook of Mineralogy). Variácie v mriežkových parametroch môžu byt' spôsobené prímesami $v$ ich štruktúre (napr. Ca alebo $\mathrm{Pb}$ ), ktoré sa ale d'alej nezist'ovali.

Valentinit je hojný na Husárke, v Suchej doline zriedkavý. Tvorí žlté až žltohnedé zemité nálety a kôry na antimonite a prerastá sa so stibiconitom. Identifikovaný bol mikroskopickým štúdiom a pomocou práškovej RTG difrakčnej analýzy; jednoznačne určený pomocou spresnených mriežkových parametrov $(a=4.64 \AA, b=12.65 \AA, c$ $=5.27 \AA$, Suchá dolina).

\section{Okoložilné premeny}

Okoložilné premeny sa sledovali na Lomnistej. Ruly a migmatity v najvnútornejšej, prížilnej zóne sú zmenené pravdepodobne na zmes fylosilikátov a horninotvorného kremeňa. Ďalej od kontaktu možno ešte pozorovat' relikty horninotvorných živcov a slúd, ktoré sú ale aj tam do vel'kej miery nahrádzané illlitom. $V$ najexternejšej zóne sa nachádzajú aj relikty biotitu, do vel'kej miery ale premenené na chlorit. Charakter aj zonálnost' premien je vel'mi podobná na alterácie na ložisku Dúbrava, kde boli aj detailne študované (Orvošová et al. 1998).

\section{Fluidné inklúzie}

Fluidné inklúzie vhodné na mikrotermometrické merania sa našli len $v$ jednej vzorke kremeňa $z$ Lomnistej (obr. 2d) a v jednej vzorke kremeňa zo Suchej doliny. $\checkmark$ obidvoch prípadoch bol hlavný rudný minerál v týchto vzorkách antimonit. Na základe detailného mikroskopického štúdia týchto vzoriek predpokladáme, že ide o kremeň, ktorý sa dá aj geneticky (t.j. nielen priestorovo) spojit' $s$ antimonitom. Všetky merané inklúzie boli primárne, dvojfázové, obsahovali kvapalnú a plynnú fázu v približne rovnakom objemovom pomere. Boli drobné $(<5 \mu \mathrm{m})$, čo znemožnilo meranie eutektickej teploty.

Salinita, vypočítaná z teplôt tavenia l'adu (s predpokladom, že prevládajúci elektrolyt je $\mathrm{NaCl}$ ) a totálne homogenizačné teploty sú vynesené v obr. 4 . Salinita sa väčšinou pohybuje medzi 10 a $20 \mathrm{hm} . \% \mathrm{NaCl}$ ekv. a je podobná pre obidve lokality. Totálne homogenizačné teploty sa však líšia. Kým pre Suchú dolinu sú tieto teploty nižšie a obmedzené na úzky interval (väčšinou medzi $200-260{ }^{\circ} \mathrm{C}$ ), rozptyl teplôt pre vzorku z Lomnistej je väčší, od 230 až po $330^{\circ} \mathrm{C}$, s jedným meraním až nad $350{ }^{\circ} \mathrm{C}$.

\section{Diskusia}

Na predmetných lokalitách sú zastúpené nasledujúce žilné minerály: Lomnistá: hlavné minerály - kremeň, pyrit a antimonit, vedlajšie minerály - arzenopyrit, Fe-dolomit, sfalerit, jamesonit, chalkopyrit, zinkenit a berthierit. Na Husárke sú hlavné minerály - kremeň, pyrit, zinkenit a antimonit, vedl'ajšie minerály - rutil, arzenopyrit, dolomit, barit, sfalerit, chalkostibit, tetraedrit- $(\mathrm{Hg})$, cinabarit, berthierit. V Suchej doline sú hlavné minerály - prevládajúci berthierit, kremeň, antimonit, pyrit a vedl'ajšie minerály - arzenopyrit, karbonáty, sfalerit, pyrotit, chalkostibit, galenit, tetraedrit-(Fe), chalkopyrit, antimón, jamesonit, zlato.

Sukcesná schéma je uvedená pre všetky tri skúmané lokality na obr. 5 . Vzácnejšie minerály $v$ nej nie sú uvedené, lebo ich postavenie v sukcesii a vztah k ostatným minerálom nebol jasný. Postupnost' kryštalizácie rudných aj nerudných minerálov je vel'mi podobná na sukcesiu na väčších Sb-Au ložiskách v d'umbierskej časti Nízkych Tatier. Salinita fluíd a neprítomnost' $\mathrm{CO}_{2}$ je porovnatel'ná s vlastnost'ami rudotvorných fluíd na iných lokalitách. Homogenizačné teploty sú však nápadne vyššie ako teploty stanovené pre fluidá geneticky spojené s minerálmi Sb (Majzlan et al. 2020). Tieto teploty sú skôr podobné na teploty zistené pre štádium, v ktorom sa tvorili pyrit, arzenopyrit a zlato. Pôvod a význam týchto rozdielov pre metalogenézu Nízkych Tatier nie je jasný.

Mineralizácia sa tvorila vo dvoch mineralizačných štádiách. V prvom vznikal najmä kremeň, pyrit a arzenopyrit. Toto štádium mohlo byt' doprevádzané intenzívnou alteráciou hornín, snád' so vznikom alteračného rutilu. Zlato ako typický sprievodca tejto mineralizácie na mnohých nízkotatranských ložiskách (napr. Magurka, Chovan et al. 1995) tu chýba.

V druhom mineralizačnom štádiu sa tvoril d'alší kremeň a karbonáty identikované ako Fe-bohatý dolomit. Zo sulfidov dominovali najmä minerály $\mathrm{Sb}$, ale prítomné sú aj iné sulfidy. Na začiatku tohto štádia sa tvorili malé množstvá sfaleritu, tetraedritu a chalkostibitu, prípadne d'alších sulfidov. Hlavný objem sulfidov vznikal neskôr. Boli to sulfosoli, zastúpené bud' zinkenitom alebo jamesonitom a jednoduché sulfidy - antimonit a berthierit.

Prítomnost' berthieritu/antimonitu alebo jamesonitu/ zinkenitu je kontrolovaná fugacitou síry $v$ rudonosných fluidách. Zinkenit a antimonit vyžadujú vyššiu fugacitu $\mathrm{S}_{2}$, druhý pár nižšiu. Pozorovanie, že zinkenit a jamesonit sa nenachádzajú na ložisku Husárka spolu, uvádza už Hak (1966). Berthierit a jamesonit uvádzajú ako časté minerály z ložiska Medzibrod Lalinská-Voleková, Chovan (2006). Zníženú fugacitu síry na Suchej doline dokazuje aj identifikácia pyrotitu $v$ týchto rudách.

Je možné, že rozdiely $v$ mineralógii odrážajú len lokálne topominerálne rozdiely, najmä vzhl'adom na hostitel'ské horniny. Horniny, ktoré obsahujú viac mafických minerálov, sú totižto schopné efektívne odstránit' síru z fluida, pričom vzniká pyrit a mafické minerály sa rozpadajú. Aj ked' uloženie rudných telies v rulách (Lomnistá, Suchá dolina) alebo v mylonitizovaných granitoch (Husárka) nesvedčí priamo v prospech takého vysvetlenia, je možné, že $v$ heterogénnom komplexe kryštalinika sa nachádzajú horninové telesá, o ktorých nemáme poznatky a sú schopné spôsobit' také rozdiely.

Ukončenie zrážania Sb výskytom primárnych Sb oxidov je známe aj z iných tatrických ložísk, najmä z ložiska Pezinok v Malých Karpatoch (Bukovina 2006), ale aj z ložiska Dúbrava (Chovan et al. 1990).

Záverom možno skonštatovat', že všeobecné rysy skúmaných mineralizácií sa neodchylujú od mnohých iných výskytov a ložísk v Nízkych Tatrách, kde sa nachádza pyrit, arzenopyrit a antimonit (Chovan et al. 1996). Je vel'mi pravdepodobné, že výskyty, ktoré sme spracovali v tomto príspevku, mineralogicky, geochemicky a geneticky úzko súvisia $s$ inými, často väčšími akumuláciami podobných rúd, napríklad na Dúbrave, Magurke, Dvoch Vodách a inde. 
Výskytom cinabaritu a tetraedritu- $(\mathrm{Hg})$ na Husárke sa dajú uspokojivo vysvetlit' analytické výsledky Haka (1966), ktorý uvádza zvýšené obsahy $\mathrm{Hg} v$ Sb rude, ale väzbu ortuti na tieto rudy nepoznal.

\section{Pod'akovanie}

Sme vd’ační Pavlíne Radkovej za vyhotovenie mapy na obr. 1. Ďakujeme Tomášovi Mikušovi a Martinovi Števkovi za recenzie, ktoré vylepšili rukopis, Patrikovi Konečnému, Danielovi Ozdínovi a Viere Kolárovej za vyhotovenie mikrosondových analýz a Petrovi Bačíkovi za pomoc pri vyhotovení RTG-difrakčných analýz.

\section{Literatúra}

Biagioni C, Sejkora J, Musetti S, Velebil D, Pasero M (2019) Tetrahedrite-(Hg), IMA 2019-003. CNMNC Newsletter No. 51

Biagioni C, George LL, Cook NJ, Makovicky E, Moelo Y, Pasero M, Sejkora J, Stanley CJ, Welch MD, Bosi F (2020) The tetrahedrite group: Nomenclature and classification. Am Mineral 105: 109-122

Biely A, Bezák V, Vozárová A, Bujnovský A, Kliniec A, Miko O, Halouzka R, Vozár J, Beñuška P, Mahel V, Kubeš P, LIŠČÁK P, LuKÁČIK E, Maglay J, Molák B, Pulec M, Putıš M, SLAVKAY M (1998) Vysvetlivky ku geologickej mape Nízkych Tatier. GÚDŠ, $232 \mathrm{~s}$

BEŇKA J, SuchÝ Š (1983) Mineralogická chrakteristika volfrámového zrudnenia v Kyslej pri Jasení. In: $\mathrm{PECHO}_{\mathrm{E}}$ J: Scheelitovo-zlatonosné zrudnenie v Nízkych Tatrách. GÚDŠ, 71-84

Bukovina J (2006) Hydrotermálny Fe-Sb-S-O systém: mineralógia a podmienky vzniku (na príklade Sb-ložísk v Malých Karpatoch). Diplomová práca, Univ Komenského Bratislava, $49 \mathrm{~s}$

Chovan M, Ragan M, SpIŠIak J, PItoñák P, Hojstričová M, Hural V (1990) Mineralógia, geochémia a petrológia žilno-žilníkovej a žilnej mineralizácie na úseku Dúbrava-L'ubelská. Záverečná správa, Univ Komenského Bratislava, $341 \mathrm{~s}$

Chovan M, Póč I, Jancsy P, Majzlan J, Krištín J (1995): $\mathrm{Sb}-\mathrm{Au}(\mathrm{As}-\mathrm{Pb})$ mineralizácia ložiska Magurka, Nízke Tatry. Miner Slov 27: 397-406

Chovan M, Slavkay M, Michálek J (1996) Ore mineralizations of the Dumbierske Tatry Mts. (Western Carpathians, Slovakia). Geol Carpath 47: 371-382

Chovan M, Slavkay M, Michálek J (1998) Metalogenéza Ďumbierskej časti Nízkych Tatier. Miner Slov 30: 3-8

HAK J (1966) Mineralogie a geochemie nízkotatranských antimónových ložísk. Sbor geol věd 7: 71-144
HANDBOOK OF MineRALOGY: http://www.handbookofmineralogy.org/pdfs/stibiconite.pdf, 26. mája 2020

KODĚRA M (editor) (1986) Topografická Mineralógia Slovenska 1. Veda, Bratislava.

LALINSKÁ-Voleková B, Chovan M (2006) Hydrotermálna mineralizácia na lokalite Medzibrod a Sopotnická dolina. Miner Slov 38: 261-272

LUPTÁKOVÁ J, PRŠEK J (2004) Sulfosoli z Pb-Zn mineralizácie na ložisku Jasenie-Soviansko (Nízke Tatry). Miner Slov 36: 286-290

LUPTÁKOVÁ J (2007) Hydrotermálna Pb-Zn mineralizácia v tatrickej tektonickej jednotke Západných Karpát. Dizertačná práca, Univ Komenského Bratislava, $201 \mathrm{~s}$

Majzlan J, Chovan M, HuRai V, Luptáková J (2020) Hydrothermal mineralisation of the Tatric Superunit (Western Carpathians, Slovakia): I. A review of mineralogical, thermometry and isotope data. Geol Carpath 71: 85-112

MıCHÁLEK J (1988) Nízke Tatry: Záverečná správa úlohy 1174 0064, Geologický prieskum n. p. Spišská Nová Ves. ŠGÚDŠ Geofond Bratislava

MoËlo Y, Makovicky E, Mozgova NN, Jambor JL, Cook N, Pring A, Paar W, Nickel EH, Graeser S, Karup-Møller S, Balic-Zunic T, Mumme GW, Vurro F, Topa D, Bindi L, BENTE K, Shimizu M (2008) Sulfosalt systematics: A review. Report of the sulfosalt sub-commitee of the IMA Commission on Ore Mineralogy, Eur J Mineral 20: 7-46

Orvošová M, Majzlan J, Chovan M (1998) Hydrothermal alteration of granitoid rocks and gneisses in the Dúbrava Sb-Au deposit, Western Carpathians. Geol Carpath 49: 377-387

Ozdín D, Chovan M (1999) New mineralogical and paragenetic knowledge about siderite veins in the vicinity of Vyšná Boca, Nízke Tatry Mts. Slov Geol Mag 5: 255271

Petrík I, Broska I, Uher P (1994) Evolution of the Western Carphatian granite magmatism: age, source rock, geotectonic setting and relation to the Variscan structure. Geol Carpath 45: 283-292

Pouba Z, VeJnar Z (1955) Polymetalické rudní žily u Jasenie v Nízkých Tatrách. Sbor Ústř Úst geol 22: 485-530

Putiš M, KRISt E, KorIKovskiJ SP, Janák M, Faryad SW (1992) Geology and Petrology of Metamorphic Rocks of the Western Carpathian Crystalline Complexes. Univ Komenského Bratislava, $324 \mathrm{~s}$

SLAVKAY M (1971) Vzt'ah niektorých nízkotatranských antimónových ložísk ku geologickým štruktúram. Miner Slov 3: 5-22 